\title{
Metallostatic pressure function in the quality of Al-Si alloy castings made in sand moulds
}

\section{Rola ciśnienia metalostatycznego \\ w kształtowaniu jakości odlewów ze stopów Al-Si \\ wykonywanych w formach piaskowych}

\begin{abstract}
The paper presents results of the studies regarding influence of metallostatic pressure of AISi7Mg alloy on surface roughness of castings prepared in sand moulds as well as on alloy's density. Castings in a cylindrical shape with a diameter of $15.0 ; 25.0$ or $3.5 \mathrm{~mm}$ and height of $700 \mathrm{~mm}$ that were cast in a vertical orientation are investigated. The melted alloy was poured into moulds in two ways: bottom up, and top down. Higher pressure and larger diameter of castings favors increase of surface roughness. In the analyzed range of height of a metal column, density increases linearly: for instance, in case of castings with diameter of $ø 25 \mathrm{~mm}$, the density increases from $\rho=2.60 \mathrm{~g} / \mathrm{cm}^{3}$ to $\rho=2.68 \mathrm{~g} / \mathrm{cm}^{3}$, what is about $0.10 \mathrm{~g} / \mathrm{cm}^{3}$. In the roller with larger diameter, the density is slightly smaller, however the range of changes along the longer axis is similar to that in the cylinder with diameter of $ø 25 \mathrm{~mm}$. Additional, ultrasonic studies were performed, which prove that with small changes of the alloy density, velocity of a longitudinal wave changes only slightly. Thus, it is difficult to control small variations $\left(\Delta \rho<0,10 \mathrm{~g} / \mathrm{cm}^{3}\right)$ in density of AISi7Mg alloy with ultrasonic technique.
\end{abstract}

Key words: aluminium casting, metallostatic pressure, density, surface roughness

\section{Streszczenie}

W pracy przedstawiono wyniki badań wpływu ciśnienia metalostatycznego stopu AISi7Mg na chropowatość powierzchni odlewów wykonywanych w formach piaskowych oraz na gęstość stopu. Badaniami objęto odlewy w kształcie walca o średnicach $d=15.0 ; 25.0$ i $3.5 \mathrm{~mm}$ i wysokości $h=700 \mathrm{~mm}$ wykonywanych w pozycji pionowej. Formy zalewano na dwa sposoby: od dołu i od

Jerzy Zych Ph.D. D.Sc., Marcin Wójcik M.Sc., Joanna Kolczyk Ph.D., Tomasz Snopkiewicz M.Sc.: AGH University of Science and Technology, Faculty of Foundry Engineering, Krakow, Poland; e-mail: jzych@agh.edu.pl 
góry. Chropowatość powierzchni zwiększa się przy wyższych wartościach ciśnienia oraz wraz ze zwiększeniem grubości odlewów. W badanym zakresie zmian wysokości słupa metalu gęstość zwiększa się w sposób liniowy. Przykładowo dla odlewów o średnicy ø25 mm gęstość rośnie od $\rho=2.60 \mathrm{~g} / \mathrm{cm}^{3}$ do $\rho=2.68 \mathrm{~g} / \mathrm{cm}^{3}$, o niecałe $0.10 \mathrm{~g} / \mathrm{cm}^{3}$. W grubszym wałku gęstość jest nieco mniejsza, a zakres zmian na wysokości jest podobny jak w wałku ø25 mm. Dodatkowe badania ultradźwiękowe pozwalają stwierdzić, iż przy tych niewielkich zmianach gęstości stopu, prędkość fali podłużnej zmienia się w niewielkim stopniu. Techniką ultradźwiękową trudno jest kontrolować niewielkie zmiany $\left(\Delta \rho<0,10 \mathrm{~g} / \mathrm{cm}^{3}\right)$ gęstości stopu AISi7Mg.

Słowa kluczowe: odlewy aluminiowe, ciśnienie metalostatyczne, gęstość, chropowatość powierzchni

\section{Introduction}

Non-ferrous metals alloys, mainly aluminium alloys and more widely magnesium alloys, are applied in technique. Alloys of this group are characterised by a strong oxygen affinity and low density. Due to these two features, different approaches to design and to cast gating systems for these alloys are required than are necessary for other casting alloys,. Especially difficult is designing the technology for castings obtained by gravitational mould fillings. Castings of this group, small in sizes, are made in the die casting technology in metal moulds. However, this specific technology is not considered in this paper. A casting production from light metals alloys, including Al alloys in sand moulds, is characterised by its own specificity.

Metallostatic pressure as a result of the metal column height in the mould is one of the most important technological factors influencing final casting quality. This pressure is important at three stages of the casting process, in the sand mould technology:

1) at the mould cavity pouring (it decides flow velocity and character - a laminar or turbulent flow),

2) during shaping, the surface layer structure of the casting (it decides, to a large degree, on casting surface smoothness),

3) during solidification (it influences density and compactness of the solidifying alloy).

Based on the investigations performed, the analysis of the metallostatic pressure influence on the quality of castings (made of the selected AI-Si alloys) is presented in the paper. This influence of pressure was analysed at all three stages of the casting process.

\section{The pressure function in the mould pouring process}

It is generally known that the laminar stream should be used for moulds filling in order to obtain castings of light metal alloys without defects. The liquid flow in channels can be either laminar (quiet) or turbulent (stormy, disordered, chaotic). In the laminar movement, individual particles are moving in straight lines parallel to the channel axis, while in the turbulent movement, particles perform several additional, very complicated, 
movements in the transverse direction despite the main longitudinal movements. The character of the liquid metal movement in the mould-gating system channels depends on: a stream velocity, alloy viscosity, shape, and size of the channel in which the flow occurs. The relationship of these values for the channel of a circular cross-section provides the Reynolds number $R_{e^{\prime}}$ equation (1):

$$
R_{e}=\frac{\theta \cdot D}{v}
$$

where:

$R_{e}$ - Reynolds number, dimensionless,

$D$ - channel inner diameter,

$\theta$ - average - on the channel cross-section - stream velocity, $\mathrm{m} / \mathrm{s}$,

$\mathrm{v}$ - coefficient of kinematic viscosity, $\mathrm{m}^{2} / \mathrm{s}$.

It was found that, for the straight channel of a circular cross-section through which water flows, this critical $R_{e}=2.320$. Numerical values of the critical Reynolds number value are within a range: from 4.500 to 50.000 . Several tests were performed to determine the allowable level of metal turbulent flow in the mould (in the case of casting light metals alloys). The author [1], who investigated flows of light metals alloys (aluminium matrix), determined that the $R_{e}$ number value for: gate runner should not exceed 10.000, sprue -7.000 , gates -1.100 , and for a mould cavity -780 .

The connection between the metal stream velocity in the gating system and metallostatic pressure is described by the Torricelli equation (2).

$$
\theta=\mu \cdot \sqrt{2 g \cdot H_{\text {met }}}
$$

where:

$\mu$ - coefficient of flow efficiency, dimensionless,

$g$ - acceleration of gravity, $\mathrm{m} / \mathrm{s}^{2}$,

$H_{\text {met. }}$ - metal column height, $\mathrm{m}$.

Unfortunately, the laminar flow is difficult to obtain (especially at high metal pressures); therefore, a mould pouring at a partially turbulent flow (when the $R_{e}$ number is slightly higher than its critical value) is allowed.

The results obtained during investigations of the Reynolds number influence [2] on the contamination degree of the test casting made of the Al alloys for two cases (straight casting and complex-shape casting) are shown in Figure 1. The $R_{e}$ number was determined for the mould cavity on the bases of the flow velocity and casting cross-section parameters (described by $R$-hydraulic stream profile). For straight shapes of the mould cavity, the build-up of inclusions starts when $R_{e}>2.600$, while for complex shapes - already when $R_{e}>780$.

Based on the obtained results [2], it is possible to compile the allowable, maximal Reynolds number values determined for individual segments of the metal flow from 
the pouring basin to the mould cavity (Tab. 1). This data can be utilised for the verifying the gating system and mould cavity filling by metal at the stage of the pouring process simulation by means of computer software. The results of industrial tests of hypoeutectic Al alloys confirmed the correctness of the $R_{e}$ number values given in Table 1 . When these values were adhered to, castings were not contaminated with oxides [2]. The data verification was also positive for magnesium alloys.

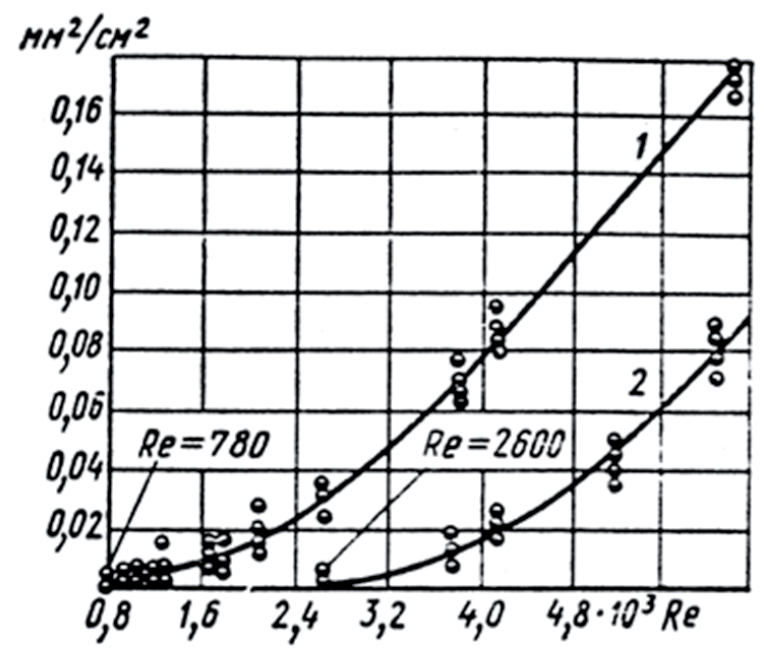

Fig. 1. Influence of flow conditions (Reynolds number) on the Al alloys castings contamination degree with inclusions, 1 - complex mould, 2-straight mould [2]

Table 1. Maximal allowable values of the $R_{e}$ number for aluminium alloys [2]

\begin{tabular}{|l|c|c|c|c|}
\hline \multirow{2}{*}{$\begin{array}{l}\text { Segment of the metal flow } \\
\text { in the casting mould }\end{array}$} & \multicolumn{2}{|c|}{$\boldsymbol{R}_{\text {e(max) }}$} & \multicolumn{2}{c|}{$\boldsymbol{\theta \cdot R}\left[\mathrm{cm}^{2} / \mathbf{s}\right]$} \\
\cline { 2 - 5 } & Acc. [1] & Acc. [9] & Acc. [1] & Acc. [9] \\
\hline Gate runner (WG) & 43.500 & 48.300 & 65.25 & 72.50 \\
\hline Sprue (WR) & 28.000 & 33.800 & 42.00 & 50.75 \\
\hline Gate (WD) & 7.800 & 5.300 & 11.70 & 7.96 \\
\hline $\begin{array}{l}\text { Mould cavity: } \\
\text { - straight } \\
\text { - complex }\end{array}$ & $\begin{array}{c}2.600 \\
780\end{array}$ & $\begin{array}{c}1.350 \\
-\end{array}$ & $\begin{array}{c}3.90 \\
1.17\end{array}$ & - \\
\hline
\end{tabular}

Metallostatic pressure by influencing the flow velocity in the gating system decides how distant the real alloy flow (most often turbulent) is from the laminar flow. At excessively high gate runners (metallostatic pressure), metal flow velocity can be slowed down by increasing the resistance of flow (increasing $\mu$ in equation 2 ) by applying filters or using complex (not straight) gate runners. 


\section{Pressure influence on casting surface quality}

The second zone in the casting process in which pressure plays an important function is shaping the casting surface state. Applying the investigation method developed in the Laboratory of Foundry Moulds Technology (Faculty of Foundry Engineering - AGH University of Science and Technology), it was shown in paper [3] that the roughness of castings made of Al alloys in sand moulds increases when pressure increases (metal column height). Investigations in this scope were continued in the research presented here. Tests were realised on cast in the form of rollers in a vertical position. The view of three rollers of the AISi7Mg alloy made in one green sand mould is shown in Figure 2a. This mould was poured with metal at temperature $T_{\text {puring }}=750^{\circ} \mathrm{C}$. Two fragments of the roller of $\varnothing 25 \mathrm{~mm}$, cut out from its bottom and upper parts, are shown in Figure $2 \mathrm{~b}$. The roughness diversification scale can be noticed in this figure (of course, this is only of the qualitative comparison character).

a)

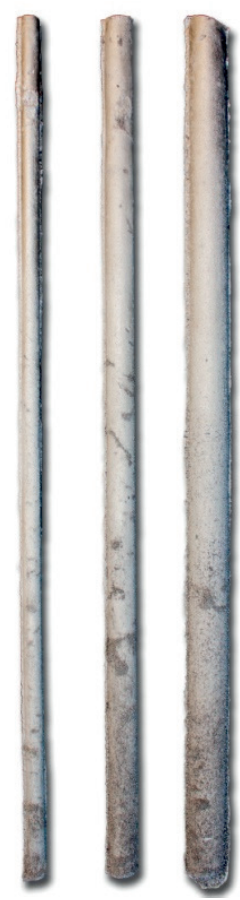

b)
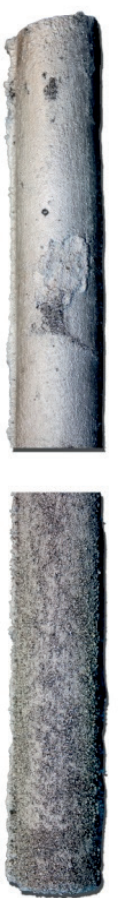

c)

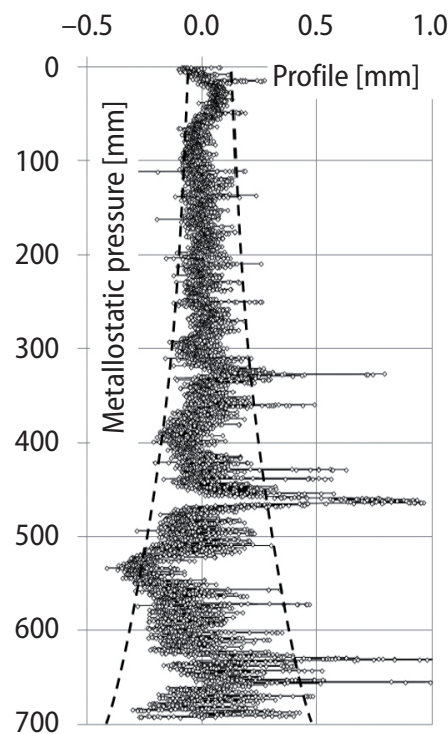

Fig. 2. Influence of metallostatic pressure (metal column height) on the surface quality of Al-Si alloys castings: a) view of surfaces of castings of various thicknesses; $b$ ) view of the surface in a closeness; c) surface roughness profile obtained by means of the laser measurement

When analysing the pressure influence on surface smoothness of the described castings, measurements of their surface roughness were also performed. These tests were carried out on the laser stand built in the Laboratory of Moulds Technology (Fig. 3). 
The non-contact surface laser profilometer was built with the application of the Computerized Numerical Control (CNC) mechanism. The CNC mechanism assures very precise head movement and scanning of the arbitrary selected segment on the sample surface. The laser converter of the OMRON Company was used as the head. After positioning the head above the measured point, the control program waits for the given time (to dampen eventual vibrations of the whole system) and takes measurements. The measurement (taking off the selected segment profile) is done by the head passing above the tested surface. The authors' own control program assures the laser converter is guided on the given path (the most often with the set and blocked $\mathrm{Z}$ axis). Measurements are saved in the text file and processed - the needed parameters are calculated. The data processing is possible even after a long time. It is also possible to measure and illustrate the surface of the object lying on a table.

The example of the recorded surface profile is shown in Figure 2c. Investigations of the profile confirm the previously-described casting surface state. Metallostatic pressure was increased to $700 \mathrm{~mm}$, which (in practice) corresponds to maximal heights of green sand moulds. Larger heights are usually not used. Envelopes of the roughness profile are marked by dashed lines in Figure $2 \mathrm{c}$. On the bases of the recorded profile, it is possible to calculate (determine) the majority of parameters describing raw surface states; i.e., $R_{a^{\prime}} R_{z^{\prime}} R_{\max }$.

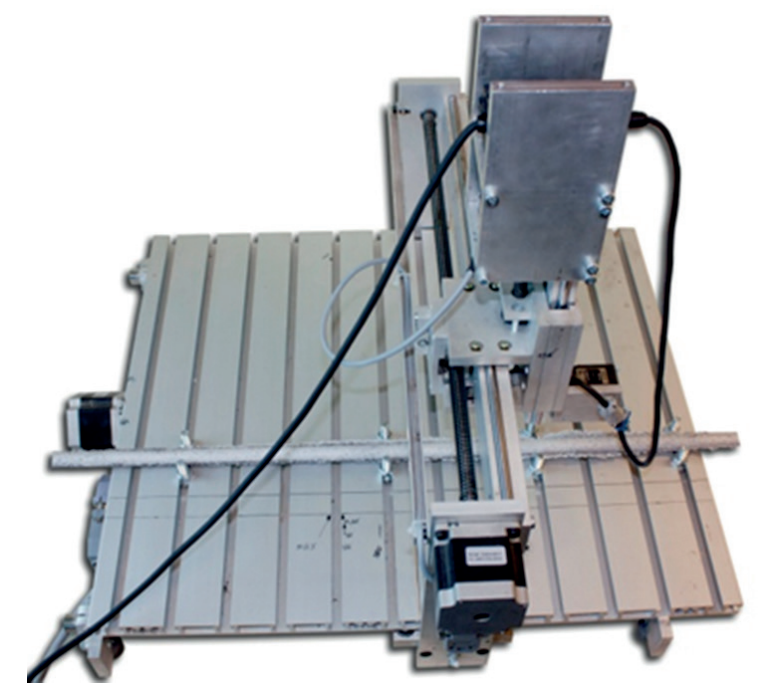

Fig. 3. Stand of the laser measurement of the roughness of the raw casting surface

The application of the new generation of profilometer should be emphasised. The non-contact measurement allows us to investigate casting surfaces of an arbitrary profile and $R_{\max }$ value. Mechanical profilometers allow us to measure the surface state up to the $R_{a}$ parameter within the range $40-60 \mu \mathrm{m}$. New measuring techniques significantly increase research possibilities. 


\section{Influence of metallostatic pressure on alloy density}

Metallostatic pressure can play an essential role in the shaping process of the macrostructure and structure compactness at making 'vertically-situated' castings characterised by relatively large dimensions (at least several dozen $\mathrm{cm}$ ). Such a situation occurs in the case of ferrous alloys, especially grey cast iron alloys. This thesis was verified in relation to Al alloys. Two sets of rollers were prepared; one mould (shown in Figure 4a) was poured from the top; the second (shown in Figure $4 b$ ) was poured from the bottom. Moulds were prepared in the 'horizontal' position while poured in the 'vertical' position. Such a pouring method allowed us to obtain a large diversification of metallostatic pressure in the mould cavities. Castings were made of Al-Si alloys (containing app. 7.0\% Si). The view of test rollers poured from the top is also shown in Figure 2a. Alloy density distribution along the height of the rollers was determined in further investigations. Rollers were cut into segments of a length of approx. $25 \mathrm{~mm}$. Density tests were performed by means of an electronic scale equipped with an attachment for measuring density 'by immersing' in a liquid. Investigations were carried out using isopropyl alcohol, what assured good wetting of sample surfaces. The obtained results are graphically presented in successive figures.

a)

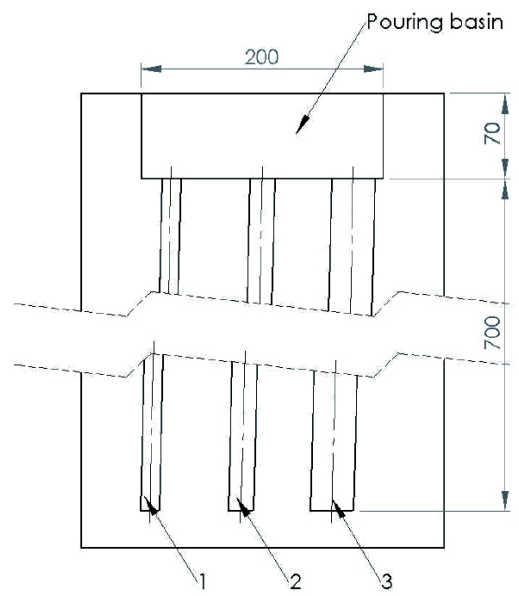

b)

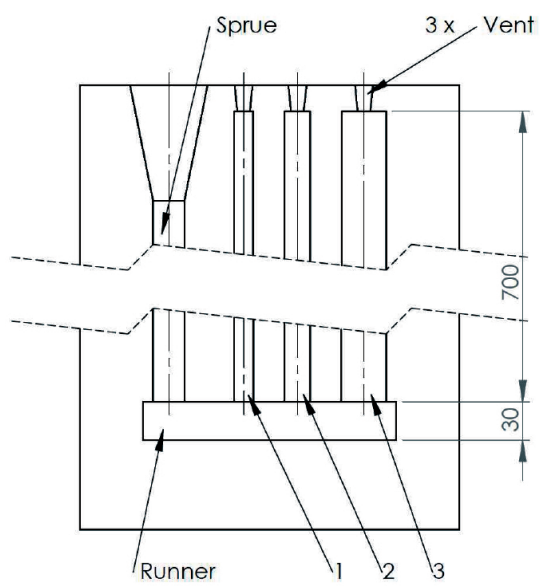

Fig. 4. Sketches of pouring systems of rollers for testing Al-Si alloys density: a) top-down; b) bottom-up system; 1- roller with ø15 mm, 2 - roller with ø25 mm, 3-roller with ø35 mm

\subsection{Pouring 'from the top'}

Alloys characterised by high oxygen affinity should be poured from the bottom while maintaining a quiet filling of the mould cavity. However, due to the necessity of dividing the mould cavity into the part located below the separation surface and located above the surface, the pouring (filling) of the mould cavity often occurs both from the top and from the bottom. 
The results of testing density distribution along a roller height with a diameter of $25 \mathrm{~mm}$ is shown in Figure 5; while in Figure 6, a roller with diameter $d=35 \mathrm{~mm}$. Rollers were poured from the top, according to the scheme presented in Figure 4a. In both cases, atypical density distribution was observed (the higher the metal column, the lower the alloy density.

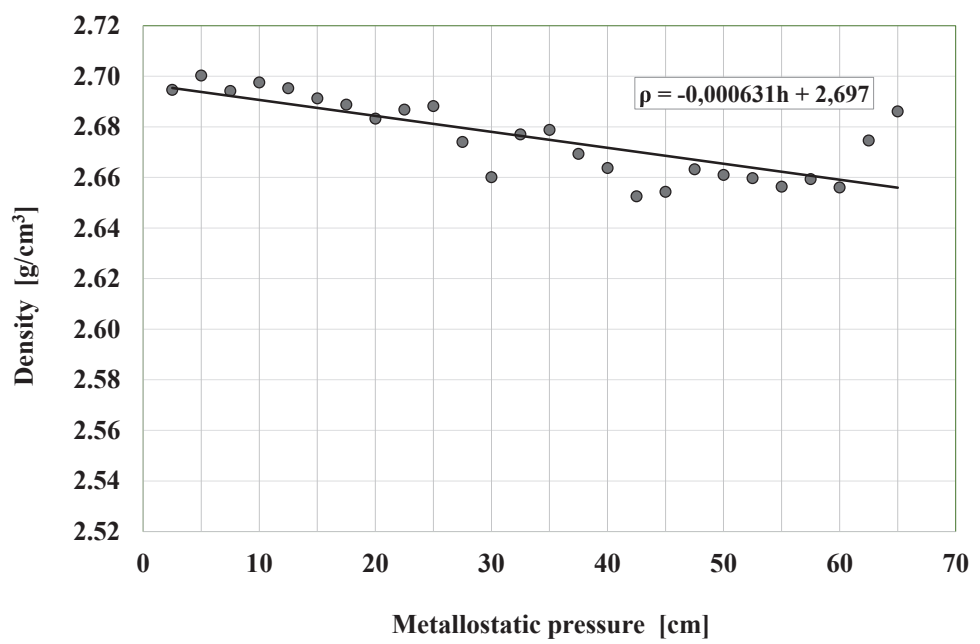

Fig. 5. Influence of metallostatic pressure on the AlSi7Mg alloy density, pouring 'from the top'; roller with diameter $d=25 \mathrm{~mm}$

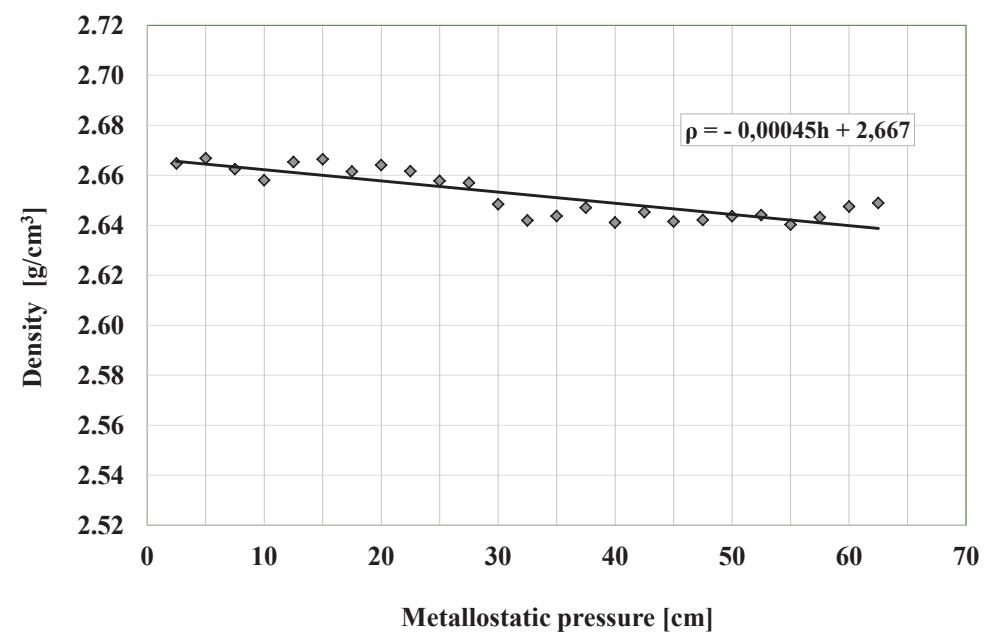

Fig. 6. Influence of metallostatic pressure on the AlSi7Mg alloy density, pouring 'from the top'; roller with diameter $d=35 \mathrm{~mm}$ 
A similar dependence was found for the roller with a diameter of $15 \mathrm{~mm}$. Several factors were imposed on the solidification process of the rollers. When pouring from the top, metal flowing to the mould cavity is subjected to very large turbulences, the largest at the beginning when it 'falls' from the highest place. In such a situation, the alloy could be more-strongly gasified in the upper part. In addition, a relatively large pouring basin crystallising for the longest time could operate as the feeder supplying the upper parts of the castings. Both effects probably outbalance the influence of metallostatic pressure, which is the highest at the bottom in places where the lowest density is found. Density differences are not large; nevertheless, a certain regularity of density distribution along each sample's height was observed. A complete explanation of this atypical effect requires further investigations on a larger number of tests. Then, more conclusions will be drawn and the effects explained.

\subsection{Pouring 'from the bottom'}

Supplementing investigations on the metallostatic pressure influence on the Al-Si alloy density, rollers were made according to the sketch presented in Figure $4 \mathrm{~b}$. These rollers were cut into short segments and subjected to density measurements. The rollers were made of the AISi7Cu2Zn2Mg1Mn alloy, which contained: $\mathrm{Cu}, \mathrm{Zn}$, and Fe.

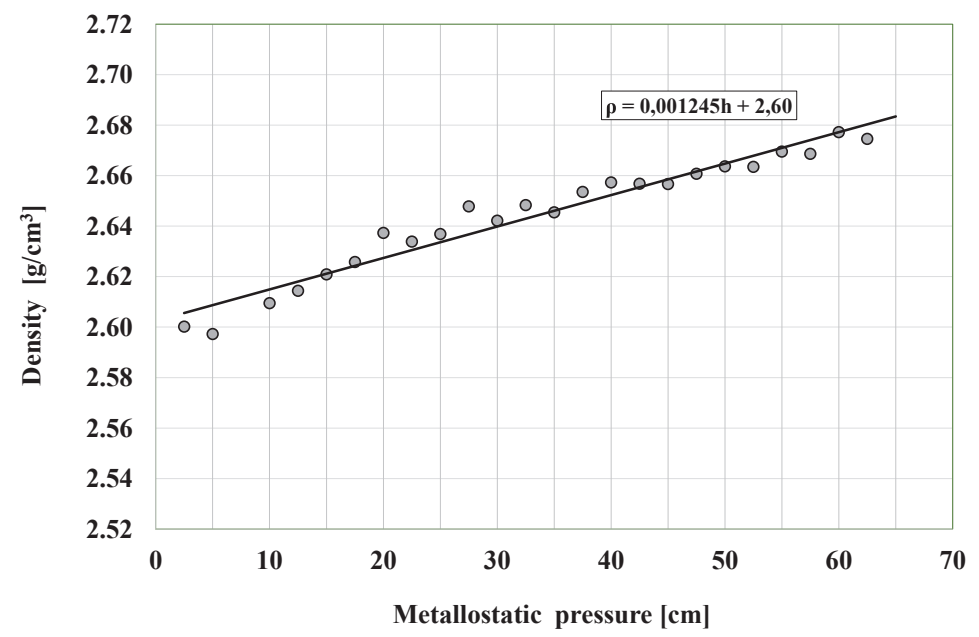

Fig. 7. Influence of metallostatic pressure, on the AISi7Mg alloy density; pouring 'from the bottom'; roller with diameter $d=25 \mathrm{~mm}$

The results of density measurements at the mould pouring 'from the bottom' are shown in Figures 7 and 8. In this case, the forecasted density distribution was obtained; i.e., alloy density increased when metallostatic pressure increased. This characteristic of the influence was observed for all tested roller thicknesses. 
When comparing the Al alloy density in rollers of various diameters, it can be noticed that the larger the diameter, the lower the density. This is seen in the case of rollers poured 'from the top' (Figs 5 and 6 ) as well as 'from the bottom' (Figs 7 and 8). Thus, the confirmation was achieved that another factor influencing the Al-Si alloy density is the solidification rate, which decreases when the roller diameter (casting wall thickness) increases.

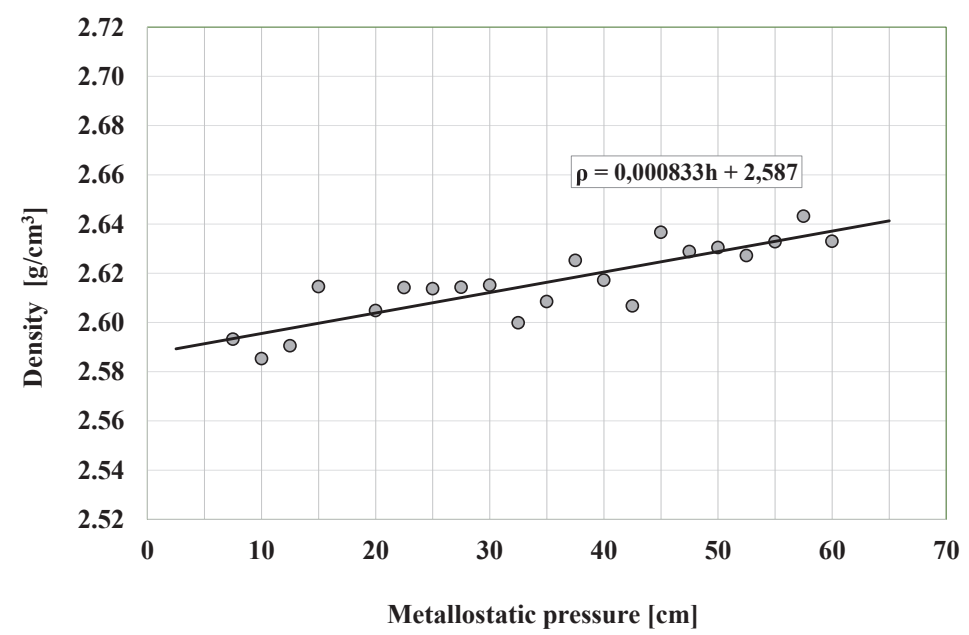

Fig. 8. Influence of metallostatic pressure on Al alloy density. Pouring 'from the bottom', roller with diameter $d=35 \mathrm{~mm}$

\section{Ultrasonic investigations}

Controlling the structure state by a non-destructive method is an attractive solution from the point of view of casting testing. Out of several known investigation methods, the most widely applied is the ultrasonic method. Endeavours to assess the structure state of rollers by means of measuring main parameters of the wave propagation (its velocity and damping) were undertaken. Density investigations indicate that along the $70-\mathrm{cm}$-high metal column, density changes are rather small, $\Delta \rho<5.0 \%$. Such small changes are difficult to be revealed by the ultrasonic technique (which was confirmed by the wave velocity tests in rollers of $35 \mathrm{~mm}$ diameter, Figure 9).

In relation to the damping coefficient, the second parameter of the wave propagation, dependence was also very poor. Thus, it can be stated that a few percentage $(<5.0 \%)$ density changes of Al-Si alloys caused by metallostatic pressure (in the range $H_{\text {met }}<70 \mathrm{~cm}$ ) are quite poorly detectable (and with a low reliability of results) by the ultrasonic technique. 


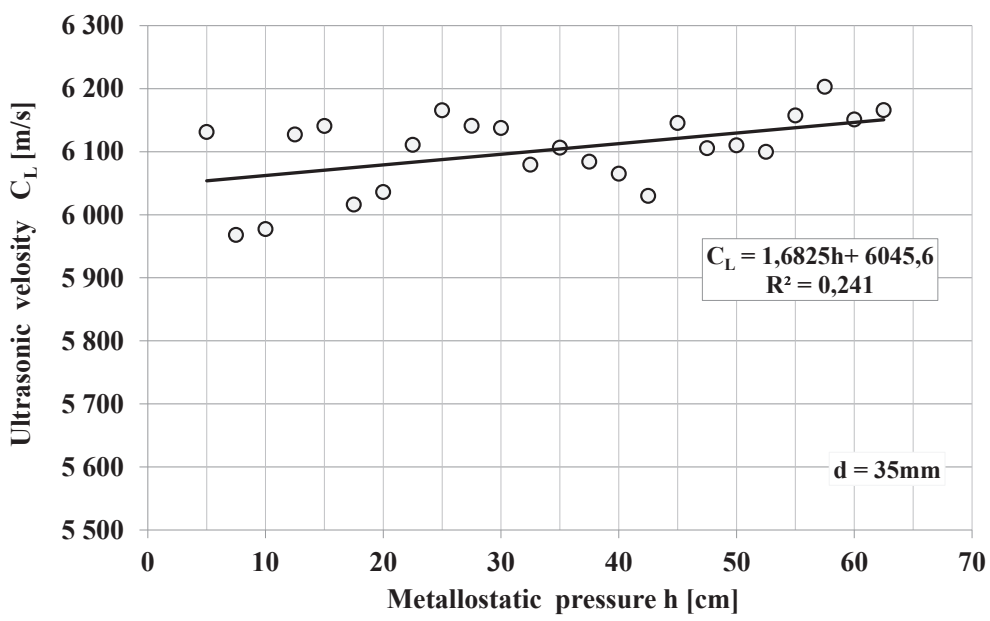

Fig. 9. Influence of metallostatic pressure during Al-Si alloy solidification on this alloy's ability to propagate the ultrasound wave (expressed by the wave velocity); pouring 'from the bottom'; roller with diameter: $d=35 \mathrm{~mm}$

\section{Conclusions}

Investigations of the metallostatic pressure influence on a broadly-understood quality of Al-Si castings made in sand moulds presented in this paper constitute a contribution to this important problem. Attempts were made to draw attention to problems which occur when making high castings. Conclusions, similar to the structure of our tests descriptions, are grouped in blocks. Based on the analysis of the effects occurring while making large castings of the Al-Si alloys in high moulds, the conclusions written below were drawn.

- When the metal column height in the gating system increases, obtaining the laminar metal flow becomes more and more difficult. In consequence, castings with oxide inclusions or gasified castings are obtained.

- Increased metallostatic pressure leads to deeper penetration of the metal into the mould and the formation of strongly-developed, very rough casting surfaces (mainly in the lower parts of the mould). This conclusion concerns green sand moulds without protective coatings deposited on their surfaces.

- At a mould pouring 'from the bottom', a metallostatic pressure increase of the Al-Si alloys causes a metal density increase. Density changes at the height $\sim 70 \mathrm{~cm}$ constitute not more than $5.0 \%$.

- At a mould pouring 'from the top', the influence of a metallostatic pressure increase of the Al-Si alloys on metal density is ambiguous. A small density decrease was found in higher-pressure zones. Unavoidably, the turbulent character of filling mould cavi- 
ties (at such pouring ways) will likely lead to a metal gasification. Density changes are quite small (up to app. 3.0\%).

- The ultrasonic technique in the simplest variant of its application (measurements of damping and velocity), but is not suitable for controlling small changes of the Al-Si alloy density.

- The additional conclusion constitutes the statement that, in the case of Al-Si alloys, the cooling rate increase (smaller wall thickness) allows us to obtain more compact structures, characterised with higher density.

\section{References}

[1] Notkin Ye.M.: Printsipy postroyeniya litnikovykh sistem dlya alyuminiyevykh splavov. [In:] Vnitol, Fasonnoye lit'ye alyuminiyevykh splavov. Mashgiz, Moskva, 1953

[2] Al'tman M.B., Lebedev A.A., Chukhrov M.V.: Plavka i lit'ye legkikh splavov. Metallurgiya, Moskva, 1969

[3] Zych J., Papaj P.: Gładkość powierzchni odlewów ze stopów Al-Si wykonywanych w formach piaskowych. IX Międzynarodowa Konferencja Naukowo-Techniczna Odlewnictwa Metali Nieżelaznych; 1-3.06. 2006, $135-140$ 